\title{
Regulatory State and Judicial Decisions in Telecommunications in Mexico
}

Submitted: $15 / 02 / 2018$

Revised: $13 / 03 / 2018$

Accepted: $14 / 03 / 2018$

\author{
Clara Luz Alvarez*
}

\begin{abstract}
Purpose - To assess the role of the judiciary in defining the Regulatory State and in regulating telecommunications in Mexico after almost 5 years of the creation of an independent regulator for telecommunications and broadcasting (Instituto Federal de Telecomunicaciones) with authority in antitrust matters.

Methodology/approach/design - To identify the most relevant judicial decisions in telecommunications and antitrust matters, research upon the context in which they were adopted, analyze the content of the decisions and identify the impact of such judicial decisions in the construction of the Mexican Regulatory State, and in the law, in regulation/acts of the regulator.
\end{abstract}

Findings - The main findings are that: (1) the Mexican Regulatory State is a reality now, even if it is in its beginnings; (2) Congress is receptive to Judiciary's decisions; and (3) deference by judiciary to the regulator is not a blank check, even if there are complex technical issues and a discretionary decision.

Practical implications - The identification of a Regulatory State in Mexico evidences that there are deep changes in the traditional relationship between Congress and regulators. Also, the deference granted by the courts to regulators must be considered as a consequence of such Regulatory State. Nonetheless and despite the deference to regulators, Judiciary's role in building the telecommunications and broadcasting sector is paramount, because judicial decisions ultimately define it.

Originality/value - Major changes to telecommunications and broadcasting have taken place in Mexico in the last years. Therefore, there has been scarce research and analysis about the new role of regulators, legislators, and judges, in the so called Regulatory State in Mexico. Moreover, the experience of Mexico may be valuable for other scholars which

*Member of the Mexican National Researchers System (level II) and researcher of the Universidad Panamericana (Mexico). She received the National Journalism Award for spreading democratic culture for her program Código Democracia at the Congress Channel (2014). Clara Luz is author of the books Telecomunicaciones y Radiodifusión en México (2018), Telecomunicaciones en la Constitución (2017), El Regulador de Telecomunicaciones (2017), Derecho de las Telecomunicaciones (3rd ed., 2014) and Internet y Derechos Fundamentales (2011), and coordinator of the book Telecomunicaciones y Tecnologías de la Información (2012). She was rapporteur for the International Telecommunications Union's study group of ICT accessibility for persons with disabilities (2006-2011), and Commissioner for the Mexican Telecommunications Commission (Cofetel, 2003-2006). Address: Universidad Panamericana. Facultad de Derecho. Augusto Rodin 498, México, Ciudad de México, 03920, México. Email: claraluzalvarez@gmail.com, calvarezg@up.edu.mx. Website: www.claraluzalvarez.org.

ALVAREZ, C. L. Regulatory State and Judicial Decisions in Telecommunications in Mexico. The Law, State and Telecommunications Review, Brasilia, v. 10, n. 1, p. 15-36, May 2018. [DOI: https://doi.org/10.26512/lstr.v10i1.21498] 
are assessing public policy in their own Latin American countries or in countries with similarities to them.

Keywords: regulatory state, telecommunications, courts, deference, discretionary

\section{Introduction}

The Regulatory State concept has entered to the legal and regulatory debates in Mexico, via judicial decisions of telecommunication cases. Also, the Mexican Supreme Court and the specialized courts in telecommunications, broadcasting and antitrust have been setting the last point in regulation since the Constitution was amended in such matters and the independent regulator was created in 2013.

This article reviews the most significant cases in telecommunications decided by the judiciary in Mexico, assessing the role that the judiciary has had to start defining the Regulatory State and the impact of such decisions in the Mexican legal framework. This is important because in telecommunications there is much more literature and research done regarding the regulators than upon the judiciary, yet the judiciary has one of the most significant participation in shaping telecommunications and broadcasting.

The background of telecommunications and broadcast is presented in Part I, referring to the emergence of such services in last century under the natural monopoly concept and passing to the privatization and liberalization of telecommunications markets in the 1990s. Then, it describes the creation of the first telecommunication regulator in Mexico with the main challenges it faced, which contributed to justify the Constitution's amendment in 2013 and the creation of a new regulator (the Instituto Federal de Telecomunicaciones or IFT) and of courts specialized in telecommunications, broadcasting and antitrust matters (hereinafter referred as Specialized Courts).

Part II starts with the acknowledgement that there is no unique concept of a Regulatory State, to continue with the analysis of the Mexican Supreme Court's decision that is the milestone for the construction of the Mexican concept of Regulatory State, as well as for the relationship between law and regulation. The Zero Tariff case is then studied due to its implications of the scope of authority of the regulator within the framework of the Regulatory State.

Part III expounds a case brought by an indigenous poet and journalist against the Telecommunications and Broadcasting Law which was decided by the Supreme Court. Although the case had no obligation whatsoever upon Congress, it decided to amend the law in order to comply with the Court's interpretation. 
The Specialized Courts have set criteria in connection to the deference granted to the regulator, which will be explained in Part IV. Then two cases in which the IFT's decisions were overturned despite such deference, will be analyzed. Finally, the conclusions of the research and analysis will be presented.

\section{Background}

Telecommunications developed during most part of the XXth Century under the natural monopoly concept which promotes having only one enterprise providing the service in order to benefit from economies of scale and to help reduce the costs of the services to the public. Pursuant to the natural monopoly, the monopoly could be public or private, local, regional or nationwide. Normally, there was a ministry as the authority with faculties to rule upon telecommunications, to overview the public or private monopoly, and to decide on public policy regarding telecommunications (e.g. universal access to telecommunication services).

Mexico was by no means the exception to the above. The natural monopoly was the rationale underlying the licenses granted to provide telecommunication services pursuant to the law (Ley de Vias Generales de Comunicaciones of 1940), and the Secretaría de Comunicaciones y Transportes (Ministry of Communications) was the authority. In telephony a private monopoly was turned to a public enterprise in the 1970s, and back to a private monopoly in 1990 (Alvarez, 2013). Cable TV licenses were granted by cities or limited geographic areas, but no additional license was granted in the same city or area, hence there were regional monopolies in this service (Alvarez 2013). Free-to-air TV channels were limited. By early 1990 as there was a major national commercial TV broadcaster (Televisa) and a couple of public channels, one of which was privatized in 1993 to a corporate group (TV Azteca) (Alvarez, 2015a).

The 1990s started with major privatizations as the public telephone company, Telmex, as well as with the execution of the North American Free Trade Agreement (NAFTA) and several agreements within the World Trade Organization (Alvarez, 2018). Mexico enacted a pro-competition telecommunications law in 1995 and created a regulator with authority in telecommunications but not in broadcasting nor did it had any authority on antitrust matters (Comisión Federal de Telecomunicaciones, Cofetel). Cofetel was an administrative body of the Ministry of Communications, with limited authority (e.g. Cofetel had no authority to sanction, nor to grant licenses) and its staff was insufficient (Alvarez, 2013).

Challenges against Cofetel's decisions were constant and injunctions to prevent enforcement of them during lengthy trials was an everyday matter. For 
example, an interconnection dispute resolution issued by Cofetel could be initially challenged before the Ministry of Communications (recurso de revisión), then an annulment lawsuit (demanda de juicio de nulidad) could be filed before an administrative tribunal (Tribunal Federal de Justicia Fiscal y Administrativa), and against the final decision of it, an amparo lawsuit could be brought before the Federal Judiciary courthouses. Neither the administrative tribunal nor the Federal Judiciary had any specialization in telecommunications, broadcasting or antitrust. Moreover, injunctions against Cofetel's dispute resolution could be granted. The litigation time could be over 3 or 4 years.

Additionally, the same acts could generate different litigation strategies, diverse moments to file the lawsuits, against different authorities and acts which could be real acts or invented ones (Roldán, 2014). The injunction (suspensión) against the acts turned out to be the main objective of a good part of the litigation strategies (Roldán, 2014). The lawsuits before the creation of the Specialized Courts in 2013, could be brought in several cities creating sometimes contradictory results in the same matters (Roldán, 2014).

"the current legal system plus the frequent use of the amparo, is the principal factor that prevents the application of regulation in Mexico. Consequently, (...) [Cofetel] is a regulatory entity incapable of regulating" (OCDE, 2012:

133) [Translation by author].

In 2013, a major amendment to the Mexican Constitution in telecommunication and antitrust took place, whereby -inter alia-, (1) a new regulator was created, the IFT, (2) the only legal remedy against acts, omissions and norms by the IFT would be the amparo indirecto, (3) no injunction (suspension) will be granted, and (4) the creation of specialized courts in telecommunications and antitrust matters was ordered.

\title{
IFT
}

\begin{abstract}
"one institutional feature that commonly emerges [within regulatory states] is the independent regulatory agency. Its popularity is often explained by its capacity to combine professionalism, operational autonomy, political insulation, flexibility to adapt to changing circumstances, and policy expertise in highly complex spheres of activity." (Yeung, 2010: section 4.5).
\end{abstract}

The IFT was established in the Mexican Constitution with the greatest autonomy that the Mexican State grants to a public entity. The IFT is independent of the traditional federal Executive, Legislative and Judiciary branches, and it is at the same level of them.

There are constitutional objectives for the IFT to pursue in telecommunications and broadcasting: their efficient development, competition and free market, as well as guaranteeing certain human rights (freedom of 
expression, right to information). The IFT is also the antitrust regulator for telecommunication and broadcasting.

\section{Only amparo, no injunction}

Any person that deems that an act, an omission or a norm (regulation) issued by the IFT infringes his/her rights, may only challenge it via a judicial review known as juicio de amparo or simply amparo. The amparo is a federal judicial proceeding for the protection and remedy of human rights and of constitutional rights infringement. The amparo will include not only IFT's act, omission or norm, but also any claim against due process, against acts performed during a proceeding, and against any law deemed unconstitutional. No injunction will be granted whatsoever.

\section{Specialized courts}

The Specialized Courts were created. There are two lower and two upper Specialized Courts with jurisdiction for all the Mexican Republic, and with domicile in Mexico City.

"This not only ameliorates the workload of other judicial institutions, but it also guarantees that the decisions are taken by public servants with enough background in these subjects [telecommunications, broadcasting and antitrust] which involve highly complex and technical issues, which in turn stimulates a better efficiency in all the judiciary and it increases the strength of judicial decisions". (OCDE, 2017: 31) [Translation by author].

It is important to note that certain telecommunication and antitrust matters may be decided by the Mexican Supreme Court. It will review amparos that challenge the constitutionality of a law, and those amparos with novel issues that pose significant impact. Also, it will decide upon disputes between public entities that challenge the scope of authority of the IFT or vice versa (controversia constitucional).

Whether the Specialized Courts or the Supreme Court, Roldan recalls Basú in their role:

"The institutional function of impartiality and objectivity do not exclude ways of thinking, ideologies, theoretical options, judges' emotions as human beings. Access to justice also has implicit the right to a human decision. (...) The experience indicates that the tribunals have been relevant actors in regulating the market and in the social regulation. When deciding disputes [judges] specify rights, obligations, restrictions, guides; or, institutional functions of the legislative, of the Public Administration, of the regulators. (Roldán, 2018: 186) [Translation by author]. 


\section{Evolution towards a Regulatory State}

There is no unique concept of a Regulatory State but rather certain common features with its own characteristics and dynamics, such features include separation between policy-making and providing of services, an independent regulator, and a decrease of state control upon national economic indicators (Yeung, 2010).

The Mexican Regulatory State emergence in the constitutional discourse appear in two telecommunication cases decided by the Supreme Court, which are explained in this section.

"The [Mexican] Court's interpretation allows to appreciate the incorporation of the Regulatory State into the judicial speech. It sets forth the main characteristics: creation of norms in a sphere that is independent of political pressures (autonomy as an institutional warranty), and of the interests of the regulated [agents] (risks of capture) in order to advance market efficiency." (Roldán, 2018: 162) [Translation by author].

\section{Construction of the Mexican Regulatory State}

Although this case's background is portability, its relevance is for the concept of Mexican Regulatory State, and the relationship between the law of Congress and the regulation by the regulator, the IFT.

The Telecommunications and Broadcasting Law entered into force in August 13, 2014, ordering the IFT to issue -within 60 business days- rules which would enable number portability to be performed in 24 hours. The IFT approved such rules in that timeframe and published them a couple of days after (Instituto Federal de Telecomunicaciones, 2014). The portability rules would enter into force in 90 calendar days after being published, and the 24-hour term would be computed considering certain business hours/days ${ }^{1}$.

The Senate considered that the IFT had invaded Congress' scope of authority insofar as the IFT published the rules outside of the term given and it ignored the 24-hour term by establishing business hours/days for it to start computing. Therefore, the Senate argued that the IFT violated the separation of power principle (principio de division de poderes), the supremacy of the law principle and the principle that law has to rule over certain matters (principio de reserva de ley).

The Mexican Court acknowledged that this case was a novel one, which evidenced a new type of constitutional engineering as both Congress and the IFT

${ }^{1}$ The 24 hours would start if the number portability request was presented before the telecom provider from Monday to Saturday from $11 \mathrm{am}$ to $5 \mathrm{pm}$. If the request was filed outside such days/times, then the 24 hours would be computed since 11 am of the next business day.

ALVAREZ, C. L. Regulatory State and Judicial Decisions in Telecommunications in Mexico. The Law, State and Telecommunications Review, Brasilia, v. 10, n. 1, p. 15-36, May 2018. [DOI: https://doi.org/10.26512/lstr.v10i1.21498] 
are created in the Constitution, so they have an equal standing, and both have express authority in the Constitution to issue norms in telecommunications and broadcasting which share the same characteristics: general, abstract and impersonal norms. In the case of Congress those norms are called laws, in the case of the IFT they are called general administrative provisions (disposiciones administrativas de carácter general) known also as regulation (regulación).

The IFT was created to regulate in favor of an efficient telecommunications and broadcasting market, and also to advance in the enjoyment of human rights as freedom of expression and right to information, as the Supreme Court identified in the legislative intent for creating the IFT.

“(...) the Regulatory State concept as a state design model created by the Permanent Constituent to address the specific requirements of postindustrial society (created by the complexity of market functioning), which confers authority to certain independent agencies - [independent] from the political bodies and from the regulated agentes - to issue regulation in certain specialized issues which are based in technical disciplines or rationales. This model of Regulatory State, by general rule, mandate the coexistence of two purposes: the existence of efficient markets, at the same time that achieving fair conditions enables the broadest enjoyment of all the human rights in the constitution". (Suprema Corte de Justicia de la Nación, 2015) [Translation by author].

The Court recognized that IFT has knowledge and capacity to issue regulation in technical matters whereas Congress has not the same expertise, and such regulation has to be frequently adapted to attain efficient markets when free market by itself cannot achieve it (Suprema Corte de Justicia de la Nación, 2015). Consequently, the IFT has authority to innovate through norms, provided they do not contradict the law (non-contradiction principle or principio de no contradicción). Moreover, if the law does not establish anything on certain issue in the realm of telecommunications and broadcasting and such issue is not expressly required by the Constitution to be in the law (reserva de ley), then the IFT can regulate freely (Alvarez, 2018).

The Supreme Court not only ruled in favor of the IFT and gave deference to its decisions regarding portability, it also established a milestone for regulators in Mexico. The decision traces the departure of the traditional conception of public administration as part of the Executive branch and of the subordination of regulation to the law. Regulation by the Executive is subordinated to the law and must not exceed what the law says. However, as a constitutionally autonomous entity outside the Executive branch, the IFT $^{2}$ may

\footnotetext{
${ }^{2}$ This would also be applicable to the Comisión Federal de Competencia Económica (Cofece) insofar as the IFT and the Cofece were created at the same time, in the same article of the Constitution and with the same faculties.

ALVAREZ, C. L. Regulatory State and Judicial Decisions in Telecommunications in Mexico. The Law, State and Telecommunications Review, Brasilia, v. 10, n. 1, p. 15-36, May 2018. [DOI: https://doi.org/10.26512/lstr.v10i1.21498]
} 
issue regulation (norms) which can go furthermore from the law, as long as it does not contradict the law.

For explanation purposes, please consider the following examples. Imagine the law says that a wall must be painted in red. If the regulation were to be from the Executive branch, then such regulation can only establish that the wall is painted with red color. If the regulation were to be from the IFT, then IFT's regulation may decide to paint it red, with different tones of red, with a rainbow and flowers to make the wall more attractive. Does this IFT regulation contradicts what the law says? No, because the wall is in fact red, yet it goes further and includes other drawings in the wall. What would happen if the law said that the wall must only be painted in red? In this case the IFT could not include the rainbow and flowers, because it would contradict what the law mandates that the wall should only be painted in red.

\section{Regulator's primary authority}

The amendment to the Constitution on telecommunications of 2013 included the creation of the concept of preponderant agent.

"[The preponderant agent] purports to identify economic agents with excessive market power and impose special obligations to cope with such power through a fast-track procedure. The IFT was mandated to determine those carriers in the telecom and the broadcast sectors that hold more than $50 \%$ of national participation in such services based on the number of users, audience, network traffic or capacity. (...) The determination of a preponderant agent by itself would not achieve any public interest objective, because knowing that an agent holds a certain market share does not correct market failures nor does it prevent abuse of market power. Consequently, the special obligations imposed to the preponderant are the instruments by virtue of which measures are established to prevent and deter any harm to competition." (Alvarez, 2015b: 16).

The IFT determined on March 6, 2014, that América Móvil and members of its corporate group ${ }^{3}$ were preponderant agents in the telecommunications sector. It also established several special obligations as interconnection rates, including termination rates. On July 14, 2014, the Mexican Congress issued the Telecommunications and Broadcasting Law which includes article 131 regarding traffic termination rates. This article states that the preponderant agents may not charge any termination rate to their competitors (known as Zero Tariff), whereas the preponderant's competitors will charge termination rates to the preponderant.

Telcel filed an amparo lawsuit against the Zero Tariff in article 131 which was finally decided by the Supreme Court. Although the main topic of the

${ }^{3}$ The economic interest group of América Móvil was considered América Móvil, Telcel, Telmex, Telnor, Grupo Carso and Grupo Financiero Inbursa.

ALVAREZ, C. L. Regulatory State and Judicial Decisions in Telecommunications in Mexico. The Law, State and Telecommunications Review, Brasilia, v. 10, n. 1, p. 15-36, May 2018. [DOI: https://doi.org/10.26512/lstr.v10i1.21498] 
lawsuit was the Zero Tariff and whether it was a confiscatory measure or whether it could be considered a taking, the Supreme Court's decision was based on IFT's constitutional authority on regulatory matters.

The Supreme Court reaffirmed that the separation of power principle is evolutionary and that the checks and balances idea underlying it, continues to be valid. The autonomy of the IFT established in the Constitution is a mean to achieve its objectives, and its scope of authority is meant to guarantee several constitutional rights (e.g. freedom of expression, right to information, right to education) (Suprema Corte de Justicia de la Nación, 2017).

So, as the Constitution itself grants authority to the IFT to determine preponderant agents, and to impose special obligations including interconnection rates, then Congress had invaded IFT's scope of authority when it mandated in the law a Zero Tariff for preponderant agents. The Supreme Court ordered the IFT to decide upon the termination tariff for the preponderant agent in telecommunication (Suprema Corte de Justicia de la Nación, 2017). In compliance with the Supreme Court's decision, the IFT determined an asymmetric tariff for termination between the preponderant agent and its competitors.

The Supreme Court's decision of this case is polemic for the effects of the judicial protection granted to Telcel, because it may not recover the termination rates from the past and the new rates started applying several months after the decision. However, this decision continues with the Regulatory State discourse by acknowledging the relevant position that the IFT as the telecommunication regulator has, and the existence of primary authority (competencia originaria) granted from the Constitution to the IFT. Such primary authority may not be disregarded by Congress.

\section{Judicial resolution, Congress action}

"By case law or binding precedents [jurisprudencia], the courts form an interpretative body which establishes the reference to appreciate the width and extent of the economic liberties or the forms of state intervention in the market" (Roldan, 2018) [Translation by author].

The Federal Judiciary may determine that a norm is unconstitutional either for a particular case when an amparo proceeding is followed and judicial protection is granted against such norm only to the person that filed the amparo, or when there is a general declaration of unconstitutionality of a norm.

For a norm to receive a general declaration of unconstitutionality (1) there must be at least five cases in which the unconstitutionality of the norm was determined via amparo proceedings, (2) the authority that issued the norm was informed of such cases where the norm was found unconstitutional, (3) the issuing authority did not abrogate or change the norm deemed unconstitutional 
within a 90 day term, and (4) the Supreme Court -by a majority of eight votes of the ministers- decides to issue the general declaration of unconstitutionality of the norm.

Congress has in general been receptive to the Supreme Court's decisions and arguments in telecommunication and antitrust, even if a provision of the law does not receive a general declaration of unconstitutionality. Under the new Telecommunications and Broadcasting Law there is one case in which Congress was not ordered to act by the Supreme Court, but it preferred to amend the law before new cases could be decided and Congress would have been obliged to act. The case involves broadcasting stations, indigenous people, and national languages as will be explained hereunder.

Besides Spanish which is spoken by the majority of Mexicans, there are 62 indigenous languages in the Mexican Republic which are mainly transmitted orally (Navarrete, 2008). It is estimated that $21.5 \%$ of the population of the Mexican Republic is indigenous based on their self-identification (Comisión Nacional para el Desarrollo de los Pueblos Indígenas, 2015). Indigenous people are distributed along the Mexican Republic either in specific locations, regions or in several states and cities (Navarrete, 2008). This is relevant when dealing with the use of distribution platforms (e.g. radio, free-to-air TV, pay TV), because in a city there may be people from different indigenous communities and with different languages.

\begin{abstract}
“(..) all the indigenous languages of Mexico share an unequal relationship with the dominant language in our country: Spanish. (...) All the laws are written in that language, the education was only in Spanish until very recently and all the government matters, and of the most rich and powerful segments of society, have been managed almost exclusively in Spanish. (...) In the last decade radio and television have granted more force to Spanish: the immense majority of the media in our country are monolingual and do not give any participation to the other languages spoken in Mexico." (Navarrete, 2008: 7576) [Translation by author].
\end{abstract}

When the new Telecommunications and Broadcasting Law was enacted in 2014, article 230 mandated that broadcasting stations must transmit in the "national language" (idioma nacional), whereas the indigenous broadcasting stations may use their own language. Although there was no reference as to which was the "national language", Spanish was understood to be the one.

Mardonio Carballo a nahuatl ${ }^{4}$ poet and journalist filed an amparo lawsuit considering that such provision discriminated him, and restricted his freedom of expression and right to information, provided that the broadcast stations where he could express himself in his native language (nahuatl) were significantly

\footnotetext{
${ }^{4}$ The nahuas are the most numerous indigenous people in the Mexican Republic.

ALVAREZ, C. L. Regulatory State and Judicial Decisions in Telecommunications in Mexico. The Law, State

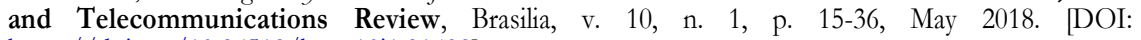
https://doi.org/10.26512/lstr.v10i1.21498]
} 
reduced to only the indigenous stations; because he was denied his right to receive information in his native language, etcetera.

The Mexican Supreme Court first of all acknowledged that the Constitution does not recognize any single language as the national one. Instead, the native languages were a material expression of the pluricultural nature of the Mexican Republic (Suprema Corte de Justicia de la Nación, 2016).

“(...) the fact that several provisions state that different procedures must be performed in Spanish, does not make it the language of the [Mexican] Nation. The concept of official language must be distinguished from that of national language. The first one refers to the language normally used when government communications are issued. Instead of that, the national language represents the language in which a country has its identity and cultural roots. Hence, even though some procedures before the government are done in Spanish, this is not the only language of the Nation." (Suprema Corte de Justicia de la Nación, 2016) [Translation by author].

Afterwards, the Supreme Court recalled that native languages and Spanish were all national languages "due to their historic origin", and that indigenous people had the right to establish their own information media in their languages and to have access to other media without discrimination ${ }^{6}$.

Any interpretation of such article 230 was contrary to the Constitution according to the Supreme Court, because it either mandated the exclusive use of Spanish or it established a preference for the use of Spanish, in detriment of native languages. Consequently, Mardonio Carballo received the judicial protection so that such article 230 of the Law would not be applied to him.

Notwithstanding that the Supreme Court's decision only benefited Mardonio Carballo, three months later Congress amended the law and complied with the arguments of the Court's decision. It is important to note that in the reports of the Deputy Chamber and of the Senate, there are certain arguments ascertaining that the Court's interpretation was not accurate, because Congress did not discriminate against indigenous languages and that the Court should have considered in its interpretation what other laws established (Cámara de Diputados, 2016; Senado de la República, 2016). Anyhow, the Telecommunications and Broadcasting Law now states on article 230: "The broadcasting stations may use in their transmissions any of the national languages pursuant to the applicable legal provisions. The indigenous [broadcasting stations] licenses may use the language of their native town".

Mardonio's case and the decision of the Supreme Court prompted the action of Congress to amend the law, even if there was no mandate to do so and despite the fact that Congress expressed that it did not share the interpretation

\footnotetext{
${ }^{5}$ Article 4 of the Ley General de Derechos Lingüísticos de los Pueblos Indígenas.

${ }^{6}$ Article 16 of the United Nations Declaration on the Rights of Indigenous People, September 13, 2007.
}

ALVAREZ, C. L. Regulatory State and Judicial Decisions in Telecommunications in Mexico. The Law, State and Telecommunications Review, Brasilia, v. 10, n. 1, p. 15-36, May 2018. [DOI: https://doi.org/10.26512/lstr.v10i1.21498] 
rendered by the Supreme Court. Once again, the Supreme Court opinion was the ship's compass for the amendment of the law in telecommunication.

\section{Court's decision for Regulator's action}

The Specialized Courts have stated that in highly complex technical matters, deference to the regulator must be granted provided that the decision in not illogic, arbitrary or abusive, that it complies with the principles which govern the administrative function and due process, that the facts are correct, that there is no evident error in the appreciation (Poder Judicial Federal, 2015).

"(...) the level of scrutiny is inversely related with the degree of freedom to decide or of the discretion that the authority has, meanwhile there are subjects as the economic and financial where discretion holds a great capacity to intervene and regulate, [and] which even if not outside the scope of control because it is limited by human rights and other constitutional provisions, does imply that judges must act without invading the authority outside their scope. In these cases, it is the regulator who must decide the ways to achieve the constitutional objectives and the type of regulatory policy, and the judges must control such decisions under the limits of the Constitution and the law, taking into account that administrative discretion implies that no authority may act outside the law, nor against it; that it must seek to achieve public interest and common welfare; its decisions must be reasonable and proportional in connection with the law objectives; effective; in good faith; not related with using public power for benefitting private interests [desvio de poder] and nondiscriminatory; provided that control upon such activity does not authorize the constitutional Judge to substitute in the [regulator's] authority to decide which is the best regulatory policy." (Poder Judicial Federal, 2017a) [Translation by author].

Moreover, when the IFT issues norms judicial review should try to preserve the regulator's decision pursuant to the Supreme Court (Suprema Corte de Justicia de la Nación, 2015). Consequently, one of the perceived risks is that so much deference to the regulator may be equivalent to denying or limiting justice to the regulated agents or to citizens, especially when technical issues are involved. The following cases evidences the approach taken by the Specialized Courts.

\section{Technical issues, the regulator's excuse?}

The metropolitan area of Mexico City has many radio stations both in AM and FM. There have been requests for new radio stations, but except for a few ones, the authority (before Cofetel, now IFT) has denied them based on technical reasons.

An association of persons -among which some argued were indigenous people (zapotecas)- requested in 2004 to the Ministry of Communications to receive the license to have a radio station in Mexico City's metropolitan area 
(Ciudad Nezahualcóyotl). As they did not receive a favorable response, in 2012 they once again requested a license for a radio station this time to Cofetel with no success (AMEDI, 2017). In 2015 they requested the license to the IFT, and the IFT responded affirming that technically there was no possibility to grant the license for an FM radio station.

The association filed an amparo lawsuit against the IFT's denial of the license. Although the second lower Specialized Court granted the judicial protection so that the IFT would duly justify its decision, the first upper Specialized Court took a different approach considering the members of the association were indigenous and also because the technical reasons for denying the license were insufficient to prove that it was sound.

"(...) the "technical studies and analysis performed by the General Direction of Spectrum Engineering and Technical Studies" which were the reason to deny the claimant's request, do not say which studies were performed, under what methodology, nor how the conclusion of non-feasibility was arrived, or if applicable, of the non-availability of spectrum, and concretely, for granting a [license for radio] station for social-indigenous programming" (Poder Judicial de la Federacion, 2017c) [Translation by author].

The first upper Specialized Courts considered that the license for the radio station was requested in order to transmit content which included those related to the indigenous community, and that several human rights were involved (e.g. right to preserve and spread the language, culture and identity of indigenous people, freedom of expression, right to access information). Also, the IFT had implemented several actions for better managing spectrum and to make more available. Consequently, it granted the judicial protection and ordered the IFT to: (1) issue a new decision considering the characteristics of the license requested and to decide whether or not it was possible to grant the license; and (2) in the event that the IFT was unable to grant the license, then it must follow up the request and, when there was availability of spectrum for the station, then the IFT must immediately inform that to the association.

Almost 5 months after the decision of the Specialized Courts the IFT granted the license for an FM station on 97.5 MHz (XHNEZ), under the name of Radio Neza (AMEDI, 2017).

Although it is a case that involves indigenous people, whereby the courts are obliged to supplement any arguments in favor of them, it evidences that the IFT may not hold technical issues as excuses. Deference does not imply a blank check for the IFT to do whatever it wants.

It is also important that the regulated entities and the citizens that challenge an IFT act or norm, provide enough information, facts and arguments against the technical aspects, otherwise the Specialized Courts may be prevented from incorporating them, except if the case involves children, indigenous people or other vulnerable groups.

ALVAREZ, C. L. Regulatory State and Judicial Decisions in Telecommunications in Mexico. The Law, State and Telecommunications Review, Brasilia, v. 10, n. 1, p. 15-36, May 2018. [DOI: https://doi.org/10.26512/lstr.v10i1.21498] 


\section{Significant market power, yes or no}

Televisa was determined by the IFT as a preponderant agent in the broadcasting sector in 2014 because it holds more than 50\% of national participation based on audience (67\% of audience share) and on the $\mathrm{MHz}$ it has been licensed (54\% of the MHz of free-to-air TV) (Alvarez, 2015a). Televisa also holds $60.6 \%$ of pay TV market $(50.1 \%$ of cable TV, and $70 \%$ of satellite pay TV) (Instituto Federal de Telecomunicaciones, 2017b).

When the Telecommunication and Broadcasting Law was published in July 14,2014 , it set forth a transitory provision which allowed any telecommunication operator (except America Movil, Telcel, Telmex and Telnor because they are preponderant agents in telecommunications), to acquire other telecommunication companies or assets without having to undergo the antitrust prior review of a merger ${ }^{7}$. This provision is evidently contrary to the objectives of prior merger review in countries with free market and antitrust laws (Alvarez, 2018).

The provision is known as Cláusula Cablecom because it had a wellknown beneficiary: Televisa. Due to its high market share in pay TV, everytime Televisa acquired a cable TV before the IFT was created in 2013, the antitrust regulator would establish several conditions for approving the acquisition. In 2013, Televisa publicly announced to the stock market that it had executed an agreement with Cablecom (a cable TV operator) which gave Televisa the option to acquire up to $100 \%$ of Cablecom shares. Therefore, the Cláusula Cablecom would enable Televisa to acquire Cablecom and any other cable TV company without being subject to any concentration review, nor to any condition by the IFT in its capacity of antitrust regulator in telecommunications and broadcasting. The same day that the Telecommunications and Broadcasting Law entered into force, Televisa announced through the stock exchange that it had acquire 100\% of Cablecom (Bolsa Mexicana de Valores, 2014).

As an illusionary measure, Congress set also another transitory provision ${ }^{8}$ in the Telecommunications and Broadcasting Law whereby it ordered the IFT to investigate whether there were operators with significant market power, specially in the pay TV market.

The Investigation Authority within the IFT holds a fair degree of independence from the Plenary of IFT, and is the authority in charge of the investigation part (Moguel, 2015). The Investigation Authority performed the

${ }^{7}$ Article transitory number Ninth of the Decree whereby the Telecommunications and Broadcasting Law was issued, published on the Federal Official Daily on July 14, 2014.

${ }^{8}$ Article transitory number Thirty-Ninth of the Decree whereby the Telecommunications and Broadcasting Law was issued, published on the Federal Official Daily on July 14, 2014. 
investigation ordered by Congress from September 2014 until January 2015, reviewing evidence from January 2009 to August 2014, concluding that Televisa held significant market power in pay TV in 2,124 markets along the Mexican Republic (Instituto Federal de Telecomunicaciones, 2015a). When the Plenary of IFT reviewed the file, it decided -in a divided opinion- that there was not enough evidence that Televisa held market power considering data from September 2013 to March 2015 (Instituto Federal de Telecomunicaciones, 2015b).

IFT's decision not to recognize Televisa's market power was widely criticized (Sosa, 2015).

"In a sophist construction, to say the least, the Institute [IFT] decides -but does not conclude - that Televisa is not dominant in pay TV. Of the 186 pages of the resolution, 183 combat one by one the evidence presented by Televisa and even support the preliminary report [of the Investigation Authority], but, all of a sudden, as a magic act, in section 4 "Conclusions of the analysis", without complying with any syllogism, without the minimum logical argumentation it "concludes" that Televisa is not dominant" (Levy, 2015) [Translation by author].

A free-to-air TV broadcaster, Televisora del Valle de México (TVM), filed an amparo lawsuit challenging the decision by the IFT. TVM argued that it had standing to pursue the amparo because if Televisa had been declared with significant market power, then TVM could receive royalty payments from the carriage of TVM signals by Televisa's pay TV companies from must-carryobligations. Moreover, TVM alleged several violations to its constitutional rights derived from IFT decision.

The first upper Specialized Court acknowledged on January 19, 2017, that TVM had standing to file an amparo against IFT's decision. Then, it analyzed IFT's decision, concluding that it did not comply with reasonableness parameters, because IFT decided based on data which was outside the scope of investigation and because not even technical aspects left to regulator's discretionary authority could oversee general legal principles (Poder Judicial Federal, 2017b).

"Therefore, IFT Plenary's decision does not comply with the reasonableness parameter provided that it is based in data outside the chronological scope ordered by the legislator, outside the reasonable timeframe foreseen by the Investigation Authority, and that imply taking into account evidence which are part of a period after the investigation was closed, making it necessary to conclude that any decision, even a discretionary one in technical aspects, is not lawful if it infringes several general legal principles such as equality before the law, legal certainty, protection to legitimate trust and good faith." (Poder Judicial Federal, 2017b: 165) [Translation by author].

Consequently, the first upper Specialized Court granted the judicial protection to TVM and ordered the IFT to repeal its decision and to issue a new

ALVAREZ, C. L. Regulatory State and Judicial Decisions in Telecommunications in Mexico. The Law, State and Telecommunications Review, Brasilia, v. 10, n. 1, p. 15-36, May 2018. [DOI: https://doi.org/10.26512/lstr.v10i1.21498] 
one in which it must analyze the evidence collected during the investigation stage by IFT's Investigation Authority. Interestingly, the Specialized Court also included a reference in connection with the asymmetric measures that IFT may eventually impose to Televisa if it had significant market power, stating that such measures must be "timely, reasonable, adequate and relevant at the time they are imposed" (Poder Judicial Federal, 2017b: 189). In other words, for determining whether Televisa was or was not dominant, IFT must only consider the investigation stage, but asymmetric measures meant to avoid abuse of such power must be considered at the time when they are ordered.

IFT, on February 24, 2017, repealed its previous decision and when analyzing the evidence in the file decided that Televisa did hold significant market power pay TV markets within the Mexican Republic (Instituto Federal de Telecomunicaciones, 2017a). Such decision has had no real implication because the IFT as of February 15, 2018, has not imposed any asymmetric measure (Levy, 2018). However, if there would be an amparo lawsuit challenging IFT's omission to impose them, the Specialized Courts will most likely grant the judicial protection and order IFT to implement the necessary measures to prevent that Televisa abuses of its market power.

\section{Conclusion}

Telecommunications laws and regulations are ultimately decided by the federal Judiciary branch in Mexico, whether through Supreme Court's resolutions or those from the Specialized Courts. The amendments to the Mexican Constitution on telecommunications, broadcast and antitrust of 2013 represent the landmark, because of the creation of the regulator (IFT) in the Constitution with broad authority, and because since then the only way to challenge IFT's actions or omissions is by amparo without the possibility of an injunction. This extreme case of only one legal remedy and no way to suspend the effects of IFT's actions, is meant to overcome the long-lasting history of uses and abuses of administrative and judicial proceedings by regulated agents to delay and prevent regulatory measures to be duly and timely implemented. Consequently, the federal Judiciary's role is of the essence for telecommunication and broadcasting, both as a market and as platforms for exercising human rights.

This article described the most significant cases decided after the constitutional reform of 2013. There are three main aspects to highlight: (1) the Mexican Regulatory State is a reality now, even if it is in its beginnings; (2) Congress is receptive to Judiciary's decisions; and (3) deference by judiciary is not a blank check to regulator. 
The Mexican Regulatory State has revealed its principal characteristics: the telecommunications regulator has equal standing with the federal Legislative, Executive and Judicial branches; regulation by the IFT may be issued as long as it does not contradict the law (non-contradiction principle or principio de no contradicción); if the law does not address certain matter and it is not constitutionally reserved for the law, then the IFT has broad capacity to innovate and develop regulation in telecommunications and broadcast, as well as in antitrust for both; due to the complexity of certain matters, the regulator -and not Congress-, is in better position to issue norms; and regulator deserves deference from the judiciary, specially in technical matters.

The interpretation, arguments and decisions by the Mexican Supreme Court and the Specialized Courts have guided Congress. Therefore, it is important that when deciding a case, the Judiciary presents and describes profoundly the underlying principles it is taking into account and its reasoning. The Judiciary has to be the lighthouse for Congress action.

Despite an ample deference granted by the Judiciary to the IFT, technical decisions or those within the discretionary authority of the IFT will be scrutinized by the courts.

Finally, it is important to note that for the Judiciary to take a stance, there must be a proceeding either (i) an amparo lawsuit by regulated agents or citizens, or (ii) a dispute over the scope of authority (controversia constitucional) or a challenge to the constitutionality of a norm (acción de inconstitucionalidad), both of which are filed by public entities. So, it can be assumed that regulated agents and public entities have the knowledge and resources to defend their interests before the Judiciary. But ordinary citizens and vulnerable groups have less chance to defend their rights; consequently, the regulator must be more proactive for such purpose and this which should be the subject-matter of a future research.

\section{References}

ALVAREZ, C.L. (2013). Derecho de las Telecomunicaciones. $2^{\mathrm{a}}$ ed., Mexico: Fundalex and Posgrado de Derecho de la UNAM.

ALVAREZ, C.L. (2015a). Mexican Telecom Reform: Private interest first? Mexican Law Review, Mexico, new series, v. VIII, n. 1, p. 47-74, JulyDecember 2015, available at http://bit.ly/1DoJksM.

ALVAREZ, C. L. (2015b). Preponderant agent, what is that? The Law, State, and Telecommunications Review, Brasilia, v. 7, n. 1, p. 13-36, May 2015 , available 
http://www.ndsr.org/SEER/index.php?journal=rdet\&page=article\&op=vi ew\&path\%5B\%5D=151\&path\%5B\%5D=109.

ALVAREZ, C.L. (2018). Telecomunicaciones y Radiodifusión en México. Mexico: Posgrado de Derecho de la UNAM.

AMEDI (2017). Neza Radio obtiene el título de concesión social comunitaria, Mexico: AMEDI, July 21, 2017, http://www.amedi.org.mx/neza-radioobtiene-el-titulo-de-concesion-social-comunitaria/ (Last accessed: January 31, 2018).

BOLSA MEXICANA DE VALORES (2014). Evento Relevante Grupo Televisa S.A.B., August 14, 2014, https://www.bmv.com.mx/docspub/eventore/eventore 544884 1.pdf (Last accessed: February 5, 2018).

CÁMARA DE DIPUTADOS (México) (2016). Dictamen sobre la Iniciativa con proyecto de Decreto por el que se reforma el artículo 230 de la Ley Federal de Telecomunicaciones y Radiodifusión, Comisión de Radio y Televisión, March 9, 2016.

COMISIÓN NACIONAL PARA EL DESARROLLO DE LOS PUEBLOS INDÍGENAS (2015). "Indicadores Socioeconómicos de los Pueblos Indígenas en México”, México: Comisión Nacional para el Desarrollo de los Pueblos Indígenas https://www.gob.mx/cms/uploads/attachment/file/239941/02-numeraliaindicadores-socioeconomicos-2015.pdf (Last accessed: February 2, 2018).

INSTITUTO FEDERAL DE TELECOMUNICACIONES (2014). Acuerdo mediante el cual el Pleno del Instituto Federal de Telecomunicaciones emite las Reglas de Portabilidad Numérica y modifica el Plan Técnico Fundamental de Numeración, el Plan Técnico Fundamental de Señalización y las especificaciones operativas para la implantación de portabilidad de números geográficos y no geográficos, published in the Federal Official Daily on November 12, 2014.

INSTITUTO FEDERAL DE TELECOMUNICACIONES (2015a). Dictamen Preliminar de la Autoridad Investigadora determinando a Grupo Televisa, S.A.B. y a las diversas Empresas Cablevisión, S.A.B. de C.V., Televisión Internacional, S.A. de C.V., Grupo Cable TV, S.A. de C.V., Innova, S. de R.L. de C.V. y a la primera de las mencionadas en su carácter de fusionante de Cablemás, S.A. de C.V. (GTV), con poder sustancial en 2,124 (dos mil ciento veinticuatro) mercados relevantes de provisión del servicio de televisión y audio restringidos, a través de 
cualquier tecnología de transmisión, con una dimensión geográfica local, March 13, 2015.

INSTITUTO FEDERAL DE TELECOMUNICACIONES (2015b). Resolución que emite el Pleno del Instituto Federal de Telecomunicaciones en el procedimiento especial, tramitado con el número de expediente AI/DC001-2014, P/IFT/EXT/300915/114, September 30, 2015.

INSTITUTO FEDERAL DE TELECOMUNICACIONES (2017a). Resolución del Pleno del Instituto Federal de Telecomunicaciones en el expediente R.A.141/2016, en relación con lo ordenado en la Ejecutoria dictada en el amparo 1675/2015 por el Primer Tribunal Colegiado de Circuito en materia Administrativa especializado en Competencia Económica, Radiodifusión y Telecomunicaciones, con residencia en la Ciudad de México y jurisdicción en toda la República, P/IFT/240217/104, February 24, 2017.

INSTITUTO FEDERAL DE TELECOMUNICACIONES (2017b). Segundo Informe Trimestral Estadístico 2017, México, http://www.ift.org.mx/sites/default/files/contenidogeneral/pagina-deinicio/2ite2017.pdf (Last accessed: February 2, 2018).

LEVY, I. (2015). "Houdini, el IFT y la no dominancia de Televisa", Mexico: El Universal, October, 5, 2015, http://www.eluniversal.com.mx/entrada-deopinion/columna/irene-levy/cartera/2015/10/5/houdini-el-ift-y-ladominancia-de-televisa (Last accessed: February 5, 2018).

LEVY, I. (2018). "IFT revierte resolución de megamulta a Telcel”, Mexico: El Universal, January 15, 2018, http://www.eluniversal.com.mx/columna/irene-levy/cartera/ift-revierteresolucion-de-megamulta-telcel (Last accessed: February 5, 2018).

MOGUEL, M. (2015). "Procedimiento de investigación y sanción en la nueva Ley Federal de Competencia Económica”, in Mena, C. et al., (Eds.). Derecho de la Competencia en México. Mexico: Porrúa, p. 179-212.

NAVARRETE, F. (2008). Los pueblos indígenas de México, Mexico: Comisión Nacional para el Desarrollo de los Pueblos Indígenas and Programa de las Naciones Unidas para el Desarrollo.

ORGANIZATION FOR ECONOMIC COOPERATION AND DEVELOPMENT (2012). Estudio sobre políticas y regulación de telecomunicaciones en México. Paris: OECD Publishing.

ORGANIZATION FOR ECONOMIC COOPERATION AND DEVELOPMENT (2017). Estudio de la OCDE sobre 
telecomunicaciones y radiodifusión en México 2017, Paris: OECD Publishing.

PODER JUDICIAL FEDERAL (Mexico) (2015). “Control Judicial de los actos administrativos de elevada complejidad técnica. Sus características", Tesis I.1o.A.E.27 A, 10 ${ }^{\mathrm{a}}$ Época, Tribunales Colegiados de Circuito, Gaceta del Semanario Judicial de la Federación, Libro 16, Marzo de 2015, Tomo III, p. 2347, 2008764.

PODER JUDICIAL FEDERAL (Mexico) (2017a). "Política regulatoria. Límites del escrutinio judicial de las decisiones relativas", Tesis I.2o.A.E.45 A

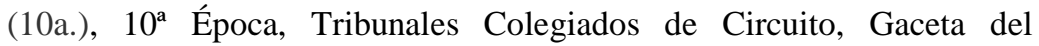
Semanario Judicial de la Federación, Libro 39, Febrero de 2017, Tomo III, p. 2325, 2013662.

PODER JUDICIAL FEDERAL (Mexico) (2017b). Sentencia relativa al amparo en revisión 141/2016, Primer Tribunal Colegiado de Circuito en materia administrativa especializado en competencia económica, radiodifusión y telecomunicaciones con residencia en la Ciudad de México y jurisdicción en toda la República, January 19, 2017.

PODER JUDICIAL FEDERAL (Mexico) (2017c). Sentencia relativa al amparo en revisión 1/2016, Primer Tribunal Colegiado de Circuito en materia administrativa especializado en competencia económica, radiodifusión y telecomunicaciones con residencia en la Ciudad de México y jurisdicción en toda la República, March 2, 2017.

ROLDAN, J. (2014). "La Licitación 21. Intereses, jueces y estrategias en la 'justicia cautelar'”, in Mariscal, J., Licitación 21, Lecciones de Política Pública en Telecomunicaciones, Mexico: CIDE.

ROLDAN, J. (2018, in press). La ordenación constitucional de la economía. Del Estado regulador al garante. Mexico: Fondo de Cultura Económica.

SENADO DE LA REPÚBLICA (México) (2016). Dictamen de las Comisiones Unidas de Radio, Televisión y Cinematografía y de Estudios Legislativos, Primera, por el que se reforma el artículo 230 de la Ley Federal de Telecomunicaciones y Radiodifusión, April 26, 2016.

SOSA, G. (2015). "Televisa gana, la sociedad pierde”, Mexico: SinEmbargo.mx, October 6, 2015, http://www.sinembargo.mx/opinion/06-10-2015/40068 (Last accessed: February 5, 2018). 
SUPREMA CORTE DE JUSTICIA DE LA NACIÓN (México) (2015). Sentencia relativa a la Controversia Constitucional 117/2014, May 7, 2015.

SUPREMA CORTE DE JUSTICIA DE LA NACIÓN (México) (2016). Sentencia relativa al Amparo en Revisión 622/2015, Primera Sala, January 20, 2016.

SUPREMA CORTE DE JUSTICIA DE LA NACIÓN (México) (2017). Sentencia relativa al Amparo en Revisión 1100/2015, Segunda Sala, August 16, 2017.

YEUNG, K. (2010). "The Regulatory State”, in Baldwin, R. et al., (Eds.). The Oxford Handbook of Regulation. Oxford: Oxford University Press, 2010, p. 64-83. 
